\title{
Conservation of Brycon orbignyanus natural populations and stocks for their reproductive, genetic, environmental sustainability: A model for species threatened with extinction
}

\author{
N. M. Lopera-Barrero \\ Universidade Estadual de Maringá, Núcleo de Pesquisa PeixeGen, Av. Colombo, 5790, 87020-900, \\ Maringá, PR, Brasil
}

\begin{abstract}
N.M. Lopera-Barrero. 2009. Conservation of Brycon orbignyanus natural populations and stocks for their reproductive, genetic, environmental sustainability: A model for threatened species of extinction. Cien. Inv. Agr. 36(2):191-208.Several ecological and climatic factors, especially those related to human activities, have been contributing to the disappearance of natural populations of piracanjuba (Brycon orbignyanus). Due to the importance of these fish to the ecosystems in which they are located and their qualities of fast growth and ability to adapt to controlled environments, producers have expressed increased interest in recent years in using this species, with particular aims of increasing production, and participation in conservation programs. In this study, strategies for the sustainable management of B. orbignyanus are idealized and discussed, with the goals of perfecting the reproductive, genetic, environmental and sanitary management of this species and suggestions for improving monitoring stocks maintained in captivity and natural populations. These strategies can be used as models for other migratory species threatened with extinction.
\end{abstract}

Key words: Animal welfare, Brycon orbignyanus, environmental conservation, fish, genetic bank, genetic conservation, piracanjuba, reproductive management.

\section{Introduction}

Genetic resources in aquaculture constitute a valuable heritage; therefore, it is essential to contribute to their conservation. For this purpose, strategies for genetic, reproductive, biological and environmental management are essential for successful programs to recover ecosystems impacted by environmental modifications.

Among the different reofilic fish species (fish emigrating during reproduction) found in Bra-

Received 06 May 2008. Accepted 29 January 2009. Corresponding author: nelson.peixegen@gmail.com zilian aquatic ecosystems, the piracanjuba (Brycon orbignyanus) has garnered interest from researchers and breeders because natural populations of this species have disappeared in recent years as a result of environmental modifications caused by human actions and climatic changes (Zaniboni-Filho et al., 2006). Therefore, it has a high risk of becoming extinct (Machado, 2005; Borba et al., 2006). Despite the presence of optimal indicators of zootechnical usefulness, which should favor the selection of this fish for fish farming, an advanced technology for their intensive cultivation remains unknown. Artificial propagation, which is useful in genetic conservation, breeding and environmental programs, has also not yet been developed for this species (Carmo and Fracalossi, 2002). 
In conservation programs, genetic diversity and genetic monitoring are necessary and important for maintaining genetic variability in populations and preventing inbreeding. Maintaining genetic variability guides the reproductive process and, therefore, dictates which methodologies should be used to avoid environmental impacts. In addition, the optimization of reproductive management and the establishment of genetic banks should enable the development of ichthyofauna restoration programs in specific biogeographic regions, and the preservation of genetic variability (Povh et al., 2008), environmental conservation, health management and stock enhancement programs (Sirol and Britto, 2006).

In addition to the benefits that molecular genetics and breeding orientation may offer to $B$. orbignyanus, additional benefits could come from using this species as a model for studies of other reofilic species. The biological, genetic and reproductive knowledge obtained for this species would help in building biological models applicable to other fish species threatened with extinction (Lopera-Barrero et al., 2007).

The objective of this study is to review and analyze the existing literature on the diversity and characteristics of some threatened species of the genus Brycon found in Brazilian continental aquatic ecosystems. At the same time, it is intended to analyze strategies for the management of the reproductive, genetic, environmental and health characteristics of natural and captive populations of $B$. orbignyanus. These strategies may serve as a basis for conservation of affected ecosystems and as a model for other reofilic fish species threatened with extinction.

\section{Diversity of fish and species threatened with extinction}

Brazil contains the largest number of hydrographic basins and the largest amount of freshwater available in the world. Additionally, it has more than $8,000 \mathrm{~km}$ of coastal regions. Consequently, Brazil contains the largest number of freshwater and saltwater fish species (Agostino et al., 2005). Froese and Pauly (2003) determined that there are a total of 3,148 fish species, including 885 marine species and more than 2,100 freshwater species (Buckup and Menezes, 2003), which accounts for almost $21 \%$ of all the fish species in the world and a large proportion of the 8,000 thousand neo-tropical species found in South America (Reis et al., 2003).

The total number of species in Brazilian aquatic ecosystems is unknown and hard to estimate, due in part to the large diversity, the lack of resources available for their study and the relatively small number of researchers. Additionally, there is a considerable number of hydrographic basins that have never been study, insufficient infrastructure for sampling them all, a small number of adequate inventories, dispersed information that is frequently not easy to access, and a need for taxonomic review of several groups (Agostinho et al., 2005).

Around 400 new fish species are described in continental waters every decade (Reis et al., 2003). Meanwhile, it is noteworthy that for only a few species is there enough information regarding their biology, physiology and genetics to understand the relationships between their environment and their cultivation medium. This information would be particularly valuable for those fish species of economic and cultural relevance and for those fish species threatened with extinction.

The genus Brycon, composed of more than 40 species, is one example of a group of fish threatened with extinction (Lima, 2003). Species of Brycon are used in commercial production and fish farming in Brazil (Wasko, 2005; NinhausSilveira et al., 2006). The Bryconids have several advantages for fish farming, including their omnivorous feeding habits and their adaptation to low levels of oxygen (Suarez-Mahecha, 2002). There is a growing search for Brycon spp. for fish farming for the following reasons: they are easy to adapt to captivity almost all over Brazil; they easily accept food of animal or vegetable origin; they grow fast; they are commercialized well; and they have a great potential for cultivation in intensive systems (Zaniboni-Filho et al., 2006).

Species of Brycon are found in all of the Brazilian hydrographic basins (Wasko and Galetti Jr., 2002). They migrate for breeding between No- 
vember and January, when food is more abundant, to ensure the survival of their offspring (Lopera-Barrero, 2005). The strategy of migrating between feeding and spawning locations allows some fish species to maximize the utilization of their ecosystem, searching for the best locations for each stage of their life cycle (Zaniboni-Filho and Weingartner, 2007). This generally occurs in rainy seasons, with high temperatures that allow for the production of high amounts of plankton (Reynalte-Tataje et al., 2002a).

Several factors, including water temperature, affect sexual maturation. It is delayed or hastened according to the winter temperature, but in general, the males breed from the time they are two years old while the females breed from the time they are three years old (Zaniboni-Filho and Schulz, 2003). Investigation of the genus Brycon has garnered great interest because of the excellent quality of its meat and its feeding habits in the natural environment, which is primarily composed of a diet of fruits and seeds. In addition, the fast growth and weight gain of this genus in experimental cultivations makes it an attractive alternative for fish farming in the Brazilian regions (Wasko, 2005). Table 1 shows the distribution and some general characteristics of a number of Brycon species, with their zootechnical characteristics.

Table 1. Scientific names and common names, distribution and some biological characteristics of species of Brycon, other than B. orbignyanus, commonly found in Brazil.

\begin{tabular}{|c|c|c|c|}
\hline $\begin{array}{l}\text { Scientific names } \\
\text { (common names) }\end{array}$ & Distribution & Characteristics & References \\
\hline $\begin{array}{l}\text { B. amazonicus } \\
(\text { Spix e Agassiz 1829) = } \\
\text { B. cephalus } \\
\text { (Günter 1869) } \\
\text { (Matrinxã, matrinchã) }\end{array}$ & Amazon basin & $\begin{array}{l}\text { It is a scale fish, with a long body with } \\
\text { slightly dark pigments in the dorsal side that } \\
\text { contrast with its silver coloration. It has fins } \\
\text { with intense black pigmented membranes. It } \\
\text { is a species with external fecundation, without } \\
\text { male care. It has omnivorous food habits, with } \\
\text { herbivorous tendencies. It fills a predator role } \\
\text { (insects, sea shell, crustaceans and small fish) } \\
\text { and is a disseminator of seeds and fruits. It is } \\
\text { appreciated for sport fishing. }\end{array}$ & $\begin{array}{l}\text { Inoue, } 2005 \\
\text { Wasko et al., } 2004 . \\
\text { Hori et al., } 2006 . \\
\text { Monteiro et al., } 2006 . \\
\text { Zaniboni-Filho et al., } 2006\end{array}$ \\
\hline $\begin{array}{l}\text { B. insignis } \\
\text { (Steindachner 1877) } \\
\text { (Pirabanha) }\end{array}$ & $\begin{array}{l}\text { Basin of the } \\
\text { Paraíba do Sul } \\
\text { river }\end{array}$ & $\begin{array}{l}\text { It is a scale fish, with a long body and silver } \\
\text { coloration. It can weigh } 8 \text { to } 10 \mathrm{~kg} \text {. It has } \\
\text { external fecundation, without male care. } \\
\text { When juvenile, it is considered ichthyophagus } \\
\text { and insectivorous, in spite of feeding } \\
\text { temporarily on leaves, fruits, and seeds. When } \\
\text { an adult, it is herbivorous and frugivorous. It } \\
\text { has delicious and highly nutritious meat. It is } \\
\text { appreciated for sport fishing. }\end{array}$ & $\begin{array}{l}\text { Sibinellii, } 2003 . \\
\text { Zaniboni-Filho et al., } 2006 .\end{array}$ \\
\hline $\begin{array}{l}\text { B. hilarii } \\
\text { (Valenciennes 1849) } \\
\text { (Pirapitanga, piraputanga) }\end{array}$ & $\begin{array}{l}\text { Basin of the } \\
\text { Paraguay, } \\
\text { Paraná, Upper } \\
\text { Amazonas and } \\
\text { São Francisco } \\
\text { rivers }\end{array}$ & $\begin{array}{l}\text { It is a scale fish. It has a dark line that extends } \\
\text { to the dark medium caudal rays. It has reddish } \\
\text { pelvic, anal and caudal fins and dark pectoral } \\
\text { and dorsal fins. It has external fecundation, } \\
\text { without male care. The male and the female } \\
\text { reach to } 20 \text { and } 25 \mathrm{~cm} \text { long, respectively, } \\
\text { when they obtain their sexual maturation ( } 2 \\
\text { and } 3 \text { years, respectively). It has omnivorous } \\
\text { feeding habits. It may reach } 56 \mathrm{~cm} \text { long and } 3 \\
\text { kg. It is used in stock enhancement programs. }\end{array}$ & $\begin{array}{l}\text { Sanches and Galetti Jr., } 2006 . \\
\text { Zaniboni-Filho et al., } 2006 . \\
\text { Graça and Pavanelli, } 2007 .\end{array}$ \\
\hline $\begin{array}{l}\text { B. microlepis } \\
\text { (Perugia 1897) } \\
\text { (Piraputanga) }\end{array}$ & $\begin{array}{l}\text { Basin of the } \\
\text { river Cuiabá, } \\
\text { Pantanal of the } \\
\text { Mato Grosso, }\end{array}$ & $\begin{array}{l}\text { It is scales fish, with external fecundation and } \\
\text { without male care. It presents omnivorous } \\
\text { feeding habits. Appreciated by its pleasant } \\
\text { flavor. }\end{array}$ & Mateus and Estupiñán, 2002 \\
\hline
\end{tabular}


Despite the noteworthy increase in the number of investigations in recent years, the information that has been obtained is still insufficient for the management of freshwater species and even more so for those species threatened with extinction, as in the case of $B$. orbignyanus. The process of extinction is related to the disappearance of species or groups of species from a specific environment or ecosystem. Modifications that occur over thousands of years allow species to adapt to their environment based on the mechanisms of genetic heredity (Sá et al., 2003). Nevertheless, the need for these modifications is currently being hastened by the environmental alterations caused by man, which make it difficult for species to adapt to their new conditions fast enough to survive and therefore cause extinction (Lopera-Barrero et al., 2007).

The list of Brazilian fauna threatened with extinction includes 44 invertebrates, 134 fish and 16 amphibians (Instructional Regulation, 3 and 5 of May, 2003 and 2004, respectively, Ministerio do Médio Ambiente, 2007). All the Brazilian states have at least one species threatened with extinction. Most of them are in the south and south west regions, specifically in the states of Minais Gerais, San Paulo, Río Grande do Sul and Río de Janeiro. This concentration of endangered species may be the result of the higher development in those regions. The largest investigations and groups of investigations in the country are also located in this region, which also is home to many endemic species with restricted distributions (Agostinho et al., 2005). There are 33 species of the Characidae family threatened with extinction, with $B$. devillei, B. insignis, B. nattereri, B. orbignyanus, $B$. opalinus and $B$. vermelha being the most threatened species (Ministerio do Médio Ambiente, 2007).

\section{Brycon orbignyanus}

Brycon orbignyanus is a reofilic species (Order: Characiformes, Family Characidae Subfamily: Bryconinae) that is native to the basins formed by the Uruguay, Paraguay and Paraná rivers (Géry and Mahnert, 1992; Borba et al., 2006; Zaniboni-Filho and Schulz, 2003). It is a scale fish with a long body, up to $80 \mathrm{~cm}$ long and $10 \mathrm{~kg}$ of live weight (Nakatani et al., 2003), and it has a wide mouth with three rows of premaxillary teeth (Nakatani et al., 2003). It has a silver coloration, a dark brown back with green reflectivity and a black spot on the base of the caudal peduncle that extends to the medium caudal rays. It has a red, bifurcated caudal fin with a dark medium line and a long anal fin of the same color (Britto et al., 2003; Graça and Pavanelli, 2007).

This species develops externally without parental care following spawning, and the semidense ova depend on water currents throughout their incubation and the initial stage of larval development (Graça and Pavanelli, 2007; Silva, 2007a). The post-larvae of B. orbignyanus are influenced by the photoperiod, having high survival rates if they are exposed to long light periods. They are carnivores, selecting food from zooplankton, and they show a tendency towards cannibalism during the post-larval and larval stages (Reynalte-Tataje et al., 2002a). The change to omnivorous and herbivorous habits probably occurs during the juvenile fish stage. This species has a great assimilation capacity for vegetable proteins (Ceccarelli et al., 2005).

B. orbignyanus is appreciated for its high nutritional value, fast growth, and good food conversion ratio. In captivity, it has good acceptance of artificial foods and agro-industrial by-products (Borba et al., 2006; Zaniboni-Filho and Weingartner, 2007). It has a surly behavior that is very appreciated in sport fishing; therefore, it has been used in stock enhancement programs for "fish and pay" ponds (Felizardo, 2008).

Natural populations of $B$. orbignyanus have disappeared because of the constant environmental alterations caused by human actions, including the reduction of food sources, predator fishing, water contamination, the building of hydroelectric plants, drainage from agriculture, the introduction of exotic species, poorly planned eco-tourism, urban expansion, deforestation and forest fires.

Currently, B. orbignyanus is a species listed as being at risk of extinction, with a low tol- 
erance to environmental alterations (Machado, 2005). For this reason, it may be regarded as an indicator species; an increase in river populations of $B$. orbignyanus is an indication of the success of stock enhancement or conservation programs for the ecosystem, shown by the survival and adaptation of the individuals to the environment. Indicator species (ecological indicators) can be defined as biological parameters (based on populations, sets of populations or systemic properties) that allow for the estimation of the ecological state of an ecosystem because of qualitative and/or quantitative characteristics they possess that enable the detec- tion and monitoring of temporary changes in a system during long periods of time (Metzger and Casatti, 2006).

\section{Conservation strategies for Brycon orbignyanus}

Genetics, breeding, and health conservation of natural populations of $B$. orbignyanus and batches maintained in captivity may be accomplished using three strategies: monitoring, the formation of genetic banks and the management of natural resources (Figure 1).

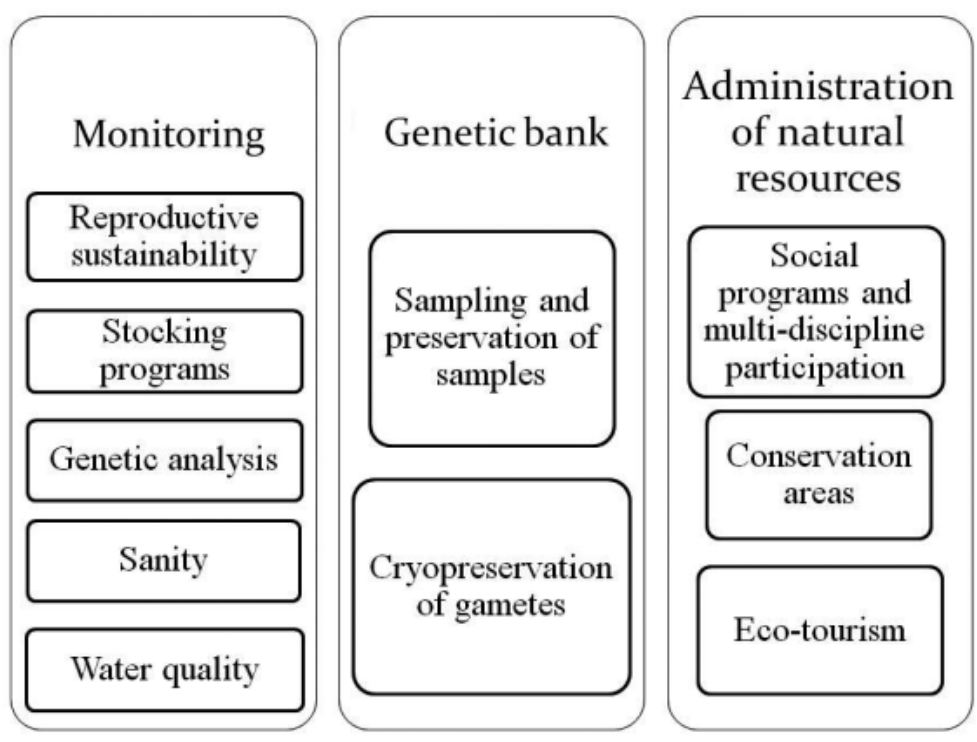

Figure 1. Strategies of the Brycon orbignyamus conservation and their main characteristics.

\section{Monitoring strategy}

A monitoring strategy facilitates optimization of the reproductive and genetic management of natural populations and batches, allowing for objective genetic improvement programs, stock enhancement programs, and studies on water quality and ichthyofauna health.

Breeding sustainability. Factors such as the loss of genetic variability of fish when raised in captivity are common, due to the effects of crossing or inadequate reproductive manage- ment (Aho et al., 2006). Therefore, there are several assumptions in reproductive management that need to be optimized for B. orbignyanus (e.g., identification of breeders, hormonal induction, crossing system, reproductive system).

The development of several fish markers has been important for ichthyologic studies. The correct use of fish markers is important for the success of fish production and the conservation of the species used in fish farming. Several types of markers, invasive and non-invasive, have been optimized in terms of their perma- 
nence, their easy identification and their effect on fish behavior during reproduction (Ferraz et al., 2004).

For non-invasive markers, methods such as removal of part of the fins, use of cables or threads, and cold marking are used. They are currently the most widely used methods for marking $B$. orbignyanus because of their low cost and their ease of use (Leboute et al., 2002; Faria et al., 2003; Ferraz et al., 2004; Zaniboni-Filho and Nuñer, 2004).

Notwithstanding the risks, invasive markers are safe and remain for a long time with a minimal possibility of being expelled. The most widely used invasive markers are elastomer markers and electronic markers (transponders) (Zaniboni-Filho and Nuñer, 2004).

One of the functions of marking is to achieve accurate reproductive management when artificial hormones are used to induce a synchronized spawning of the breeders. The use of extract from the hypophysis of mature fish, in spite of being an old procedure, remains one of the most widely used techniques to induce a final maturation of the Brazilian migratory fish (Zaniboni-Filho and Nuñer, 2004). There are countless variations of methods of hormone management in fish, depending on the type of hormone and the type of fish to be induced. Females generally require higher doses of hormones than males. In B. orbignyanus, two applications are normally required in females ( $10 \%$ of hormones are given in the first application to stimulate the migration of the germinal vesicle, and $90 \%$ in the second to break it and produce the spawning $24 \mathrm{~h}$ later) and only one in males $(100 \%$ at the time of the last application in females) to obtain successfully synchronized spawning (Lopera-Barrero, 2007). The application is intramuscular or intra-peritoneal. As the process of induction is a simulation of what occurs in the natural environment, the process of final maturation depends directly on the species and the temperature in the ponds where the breeders are maintained.

Once the $B$. orbignyanus breeders are hormonally induced, they are ready for crossing. The crossing system is commonly managed at ran- dom for the artificial reproduction of breeders maintained in captivity. To compensate for the low amount and quality of semen induced hormonally, many fish farms use a great number of males, or semen from more than one male, to fertilize the female ova (Zaniboni-Filho and Nuñer, 2004). The reduction in the volume and quality of semen is attributed to the stress that the animals suffer during the reproductive process. Despite the positive purpose, it is feasible that this crossing system reduces genetic variability, decreases viability, and lowers the survival of batches and offspring in fish farming (Lopera-Barrero, 2007).

Therefore, it is recommended to maintain the effective number of breeders at as high a number as possible and to perform spawning with an equal proportion of sexes in order to maintain the genetic potential of a batch or breeder population, which can maintain the genetic diversity (Brown et al., 2005; Frost et al., 2006). Some studies have shown the influence of crossing systems on the genetic variability of batches in fish farming. Lopera-Barrero (2007) studied two types of crossing (1:1 and 2:1, male:female) in the semi-natural reproductive system, and found a loss of genetic variability in the system that used two males for each female (2:1) according to the Shannon's index of genetic diversity $(\mathrm{SI})($ breeders $=0.2153$; larvae $=0.1882)$ and the percentage of polymorphic fragments (PF) (breeders $=34.44 \%$; larvae $=33.33 \%$ ). Another study (Povh, 2007) that compared the semi-natural spawning system and an extrusion system for a "pacu" (Piaractus mesopotamicus) batch found an increase in the genetic variability of the batch managed by the semi-natural system $(\mathrm{SI}=0.365$ and $\mathrm{PF}=60.5 \%$ ), using a $1: 1$ crossing system.

Once the crossing system is established, the reproductive system where the fish are going to cross must be defined. There are two reproductive systems for reofilic species, semi-natural and extrusion systems (Zaniboni-Filho and $\mathrm{Nu}-$ ñer, 2004). The reproductive extrusion system by is one of the most widely used in Brazil (Andrade and Yasui, 2003). Most of the fish farms have used this spawning system, which does not require reproduction or spawning ponds, allows for an easy gamete management that is set up 
for improving and selecting programs, and reduces the labor force needed in the procedure. However, some fish species are generally very sensitive and undergo high stress in this reproductive management system, resulting in high rates of mortality.

The semi-natural reproductive system has scarce interference from the breeder in the reproductive process, simulating natural breeding conditions. In this system, after the hormonal induction, females and males are placed inside a reproduction pond (simulating satisfactory environmental conditions), where ova fertilization occurs directly and randomly by males (LoperaBarrero, 2007).

For Leporinus macrocephalus, the semi-natural reproductive system allowed a higher rate of breeding survival and a higher rate of ova fertilization than the extrusion system (ReynalteTataje et al., 2002b). When analyzing the genetic variability of batches of $P$. mesopotamicus in the semi-natural reproduction system and the extrusion system, Povh (2007) found a higher genetic diversity in the semi-natural system than in the extrusion system, and concluded that the semi-natural reproductive system must be used when the purpose of fish farming is the production of fingerlings or juveniles for stock enhancement programs. This recommendation was confirmed for B. orbignyanus, which experienced no breeding mortality in the seminatural system and exhibited higher genetic diversity among offspring using the 1:1 crossing system (Lopera-Barrero, 2007). However, additional analyses are needed to confirm the efficiency of this system for preserving the genetic variability of other migrant fish species.

Stock enhancement programs. To rehabilitate reduced fish, stock enhancement programs are essential to maintain the genetic variability of the native population, an aspect that should be considered when releasing fish into the environment for stock enhancement programs. Since native species have been heavily impacted, it is evident that breeding on fish farms may be an alternative for restoring fish populations (Povh et al., 2008). Therefore, fish stock enhancement programs in rivers can promote the conservation of genetic resources, especially when there is a risk of extinction (Barroso et al., 2005).

Stock enhancement programs must be widely discussed and informed by scientific knowledge (Sirol and Britto, 2006). Offspring obtained for stock enhancement programs are normally obtained from crossings of few fish pairs, which temporarily reduces the genetic variability (Povh et al., 2008). Consequently, irrational introductions of fish may reduce the genetic variability of populations, thereby potentially causing a loss of resistance against diseases, reducing the capacity for fish to adapt to changes in their environments and genetically altering natural populations (Taniguchi, 2003; Leuzzi et al., 2004; Sønstebø et al., 2007).

Thus, for conservation of the genetic diversity of natural populations of $B$. orbignyanus, all the fish released during stock enhancement programs must represent the populations genetically. This standard can be accomplished by using an effective number of breeders (a minimum of 12 per crossing) from populations with a genetic composition similar to natural populations that have preserved their genetic variability (Lopera-Barrero, 2007). In order to fulfill these requirements, molecular markers (e.g., randomly amplified polymorphic DNA (RAPD), microsatellites) are used extensively (Liu and Cordes, 2004; Povh et al., 2008).

Genetic analysis using molecular markers. Determining the distribution of the genetic variability within and among populations is an important step for planning successful in situ conservation and repopulation programs. For this analysis, one must consider if a particular species is distributed in a single population or if there are multiple genetically distinct populations. At the same time, it is necessary to know the level of interaction among populations. In freshwater fish, populations are distributed throughout isolated locations, which may minimize the genetic interchange among them, leading to processes of genetic differentiation (Hilsdorf and Petrere Jr., 2002).

Genetic analysis of non-invasive samples may be carried out with the help of molecular markers (Lopera-Barrero et al., 2008a). Fish maintained in controlled environments may be exposed to a decrease in genetic variability due to the effect 
of crossing among related individuals. This tendency was observed for B. orbignyanus, where a similar genetic variability was found among batches of different origins (Lopera-Barrero et al., 2006).

The first step for implementing fish farming or programs of genetic improvement and repopulation of $B$. orbignyanus is to verify the genetic variability of the batches and the genetic structure of natural populations in order to select individuals that effectively contribute to forming a batch with a genetic base wide enough for such purposes (Lopera-Barrero et al., 2007). Therefore, molecular markers are a useful tool, and they are safe. Among the several molecular markers developed in recent years, Random Amplified Polymorphic DNA (RAPD) markers and microsatellites are the ones used the most in studies of fish genetics and in conservation and genetic monitoring (Wasko and Galetti Jr, 2003; Liu and Cordes, 2004; Povh et al., 2008; LoperaBarrero et al., 2008b). Accordingly, studies that determine the variability and genetic structure, parentage and breeding of fish populations (e.g., B. orbignyanus) provide important contributions to the knowledge concerning the conservation of exploitable ichthyological resources.

Fish health. The information that exists concerning the conditions that promote parasitism in controlled and natural environments is limited for freshwater species in Brazil. Still, the intensive cultivation of fish, due to factors inherent in this activity, favors the occurrence of some infectious and parasitic diseases (Braccini, 2007). Currently, the prevalence of fish diseases is a problem in Brazilian fish farming (Dias et al., 2004).

Whether from natural or artificial water systems, fish are infected by numerous parasites, protozoans and metazoans that may be found on the body surface (ectoparasites) or in the internal organs (endoparasites). If these organisms do not cause death, they generally cause lesions in the tissues that compromise the quality of meat for human consumption (Pavanelli et al., 2002; Fonseca and Silva, 2004). The aquatic environment enables access and penetration of pathogenic agents, and fish containment favors the appearance of diseases that cause high rates of mortality due to the lack of knowledge about the proper conditions for management, facilities, population density and nutritional needs (Gomes et al., 2003; Vargas et al., 2003). Thus, it is important to know the different fish diseases, their favored environmental conditions, their transmission processes, their prophylaxes, and how to diagnosis their presence and, when necessary, to be able to administer specialized treatments (Pavanelli et al., 2002).

The protozoan Trichodina spp. and species Dactylogyridae, the main parasites present in captivity environments and Brazilian rivers, may enable secondary infections by opportunistic bacteria by suppressing the immune system of the fish. These parasites are favored during certain phases of growth and seasons of the year, by high population densities, in certain species and sexes, and by poor water quality (Vargas et al., 2003; Azevedo, 2004; El-Sayed, 2006; Schalch et al., 2006). Other diseases that cause high mortality (e.g., Flavobacterium columnare) also affect several tropical species of freshwater fish, including $B$. orbignyanus, and cause economic losses due mainly to difficulties with their isolation and characterization (Pilarski et al., 2008).

To develop effective techniques for controlling parasites, it is necessary to determine the epidemiological, environmental and health conditions that will inhibit parasitism in fish farms (Schalch and Moraes, 2005). Fish are extremely sensitive to many aquatic pollutants, especially to those contaminants that affect their permeability to water and ions. The branchial epithelium plays an important role in the osmotic and ionic pressure of fish, and cells forming that epithelium respond directly or indirectly to environmental factors and internal alterations of the organism (Lupi et al., 2007).

Morphological alterations of gills, as well as livers and kidneys, may be used in investigations to characterize the toxicity from specific chemical compounds and to monitor their acute and chronic effects on contaminated aquatic environments (Lupchinski Jr. et al., 2006; Lupi et al., 2007). Thus, gills can be used as biomarkers for monitoring ecosystems in conservation programs as a method of environmental monitor- 
ing of ecosystems. According to Adams (2002), the term biomarker of environmental pollution refers to a specific organ that suffers morphological alterations, structural alterations in cells and/or tissues, and/or performance alterations as a consequence of exposure to a pollutant. Signals that are evidence of toxicity include a decrease in feeding, a loss of balance and pigmentation, and death, and they are preceded by biochemical, physiological and morphological changes of the organism (Akaishi, 2007).

Water quality. Human population growth causes an increase in the exploration for and use of water, resulting in an increase in all types of residual waste waters. This growth without any planning leads to the depletion and pollution of water resources. The decrease in the availability of water resources and the impacts on surface and ground water quality necessitate a renewed tendency towards the rational utilization of wate, minimizing the damage to the environment. During the process of fish farming, the accumulation of organic and metabolic residues in ponds is inevitable, especially in systems of intermittent water renovation. The volume of feces excreted daily by the fish population is one of the main sources of organic residues in fish farming (Hussar et al., 2005).

In fish farming, the farmer must know the quality, amount and origin of water, and accept the pre-established standards and parameters. The overall water quality in fish farming is the result of external influences (e.g., the quality of the water source, soil characteristics, climate, the introduction of foods) and internal aspects (fish density and physical, chemical and biological processes, in addition to the characteristics of the pond construction, Bastos, 2003). The main pollutant sources of the aquatic environment in fish farming are the food and fish metabolites, which introduce high levels of nitrogen and phosphorus (Medeiros, 2002).

The integrated management of water resources is based on the perception of water as part of the ecosystem. In addition to being a natural resource, it is an economic and social good, whose adequate amount and quality determines the nature of its use. Water must be protected due to the crucial importance of aquatic eco- systems for the satisfaction of current and future human needs (Garutti, 2003). For example, Toledo et al. (2003), when analyzing the water quality of a fish farm in the municipality of Alta Floresta-MT, found statistically significant differences between the water supply to ponds and the water outflows from those ponds. On the other hand, Sipaúba-Tavares et al. (2008), when analyzing the influence of water quality and zooplankton abundance on the performance of B. orbignyanus larvae, stated that the physical, chemical and biological variables of water determine the yield of larvae in ponds, necessitating the constant control and monitoring of this resource.

As the number of fish farms increases, most of them without technical support, there is an urgent need for studies on the impact on water quality in bodies of water that receive the outflows from fish farms (rivers, lakes, lagoons), mainly due to the organic matter and nutrients that are released daily into the rivers and streams of the region (Silva, 2007b).

\section{Strategy for establishing genetic banks}

Strategies that use biological material to add to the current knowledge on the genetic diversity and molecular biology of fish species are desirable and necessary. For example, DNA storage has been useful for studies on epidemiology and population genetics (Egito et al., 2005). In this context, the formation of genetic banks containing tissue samples, DNA samples and cryopreserved gametes are important for characterizing and conserving the genetic resources of ichthyofauna.

Sampling and sample preservation. A great number of genetic studies on fish have been carried out in recent years using protocols based on DNA analysis. However, the feasibility of these studies is frequently limited by the ability of the researchers to isolate DNA in an acceptable amount and quality (Aranishi, 2006; LoperaBarrero et al., 2008a).

Two procedures may be generally used to obtain DNA samples: invasive sampling and non- 
invasive sampling. Invasive sampling uses surgical methods to retrieve samples of normal tissues, causing lesions that may act as an entrance for infections that cause the death of animals. Non-invasive sampling is more attractive and more widely used, as it is possible to obtain good quality DNA samples from external tissues, blood (Pineda-Santis et al., 2004), scales (Wasko et al., 2003), mouth cells (Livia et al., 2006), muscle (Sofia et al., 2006), and ova (Aranishi, 2006). Fin samples have been used successfully in B. orbignyanus because of the simplicity of collection and preservation (usually in 70 or $100 \%$ ethanol), the ease of the extraction protocol, and the amount and quality of DNA extracted (Wasko et al., 2003; Gomes, 2007; Povh, 2007; Lopera-Barrero et al., 2008a).

Gametes cryopreservation. Another method used for the conservation of B. orbignyanus is the cryopreservation of semen and embryos. The biotechnology for gamete cryopreservation guarantees the preservation of genetic material for many years, which provides a reserve of good quality genetic material that can be used for a variety of investigations in different areas (Streit Jr., 2005).

The use of a semen bank in programs aimed at conserving genetic resources has several advantages, including the reduction in the number of male breeders used in programs for artificial propagation, the ability to simultaneously manage breeders during any season of the year, the orientation of programs towards genetic improvement, the procurement and management of genetic material for the analysis of genetic diversity, the elaboration of genetic banks, and the conservation of species regarded as at risk of extinction (Carneiro, 2007). For these purposes, intracellular cryoprotectors (e.g., dimetilsulfóxido, methanol, glycerol) and extracellular cryoprotectors (e.g., sacarose, glucose, polymers, and proteins such as those from the egg bud) have been used. In combination, cryoprotectors can provide a more complete protection for cells because they act at the level of the cell membrane (Lopera-Barrero, 2007).

The conservation of fish embryos by cryopreservation is not yet feasible because of factors such as cold sensitivity, differences in membrane permeability and the amount of vitelum (Streit Jr. et al., 2007). On the other hand, studies have shown that the establishment of a protocol for the cold-preservation of embryos is near (Ahammad et al., 2002). Of the possible applications of cold-preservation of embryos, the main ones are as follows: enabling species reproduction when there is not reproductive synchronism, allowing the collection of embryos from remote places, and maintenance of embryos in cool conditions until incubation (Ahammad et al., 2003).

\section{Management strategy for natural resources}

The possibilities for ichthyofauna management that may be successful in natural environments affected by human action include implementation of catch periods, definition of catch quotas, normalization of types of equipment allowed for catch, restoration of spawning and growth areas, fishing control (season, place, minimum size of catch), improvement and restoration of natural environments, and construction of fish passage mechanisms (stairs and elevators) (Agostinho and Gomes, 2006; Sirol and Britto, 2006) if there is an adequate management and control of the natural resources.

According to Agostinho et al. (2005), the programs for ichthyofauna conservation must involve four objectives. First, fish management has to provide equal priorities for fish production and biodiversity restoration. Second, management actions must emphasize the preservation of the integrity of ecosystems, mainly in areas critical for the life cycle of the species existing in the basin. Third, all management actions must be followed by subsequent monitoring. Fourth, the legislation and control of fishing require an efficient system of communication that is realistic and has clearly defined objectives, as well as a wide participation of fishermen organizations and society.

Social programs and multidisciplinary participation. The components of a conservation program for aquatic resources, in addition to requiring monitoring strategies and the formation 
of genetic banks, also need social participation and support from other areas, which promote the development of regional conservation programs and foster new alternatives for the local and regional economy.

Several areas must participate in all of the programs for the conservation of species threatened with extinction. Part of the success of the programs will depend on the multidisciplinary formula and scientific linkages. The integration of environmental, biological and agrarian sciences and the participation of companies that generate energy are important. It is from their scientific contributions that the management objectives and procedures, the definition of the species that will be repopulated, the locations and periods of release, the amount and frequency of releases, the protection of genetic diversity and the protection of the ciliary mata and the ecosystem may be objectively defined (Lopera-Barrero et al., 2007).

Participation by the biological and environmental sciences in characterizing the limnology and monitoring the water quality of rivers and fish farms and by the forestry and agronomic sciences in proposing campaigns of reforestation and protection, as well as application of ecotechnology to increase the participation and education of the population are some examples of how multidisciplinary participation can help in the preservation fish species.

Conservation areas. The selection of areas destined for species conservation is normally carried out on the basis of criteria of pristineness (natural and wild environments, with an idealized absence of human interference) and scenic beauty (Metzger and Casatti, 2006). This process has resulted in a tenuous distribution of conservation units (or reserves) generally in remote areas with higher altitudes, rough relief and poor soils and in areas where the economic exploration of the territory was harder to accomplish or less productive (Groves et al., 2002).
In order to avoid this obstacle, it is necessary to establish more objective biological criteria for selecting areas of conservation, such as representativeness of a wide range of attributes related to biodiversity or preservation of biological integrity to ensure the persistence of populations during extensive periods of time (Gaston et al., 2002; Gaston and Rodrigues, 2003). It is important to define objectives for conservation, evaluate the existing reserves, select new priority areas, and to implement feasible management programs for the reserves (Metzger y Casatti, 2006).

Ecotourism. Studies that have monitored the impacts of ecotour visits to Neo-tropical freshwater environments are rather limited and practically non-existent in Brazil (Sabino and Andrade, 2002). For a correct ecotourism practice, protocols must be established for visits that aim to diminish the conflict between recreation and the conservation of nature (Terborgh et al., 2002), prepare the visitor to understand and respect the environment (Sabino and Andrade, 2002), and avoid negative impacts on sensitive components of the environment (Hiddink et al., 2006).

From an analysis of the existing literature, it can be concluded that management of $B$. orbignyanus and the conservation of its ecosystem may provide a system for developing sustainable models for management of natural populations and breeders maintained in captivity that can then be applied to other migrant species threatened with extinction.

Finding the balance between economic interest (private) and environmental conservation (public interest) is not an easy task, mainly because the control of this balance depends on criteria that are subjective in nature and on adequate environmental and tourism policies (Sabino and Andrade, 2003). A scientifically oriented monitoring program diminishes this subjectivity, as it includes the evaluation of quantifiable biotic and abiotic components (Sabino and Andrade, 2002). 


\title{
Resumen
}

\begin{abstract}
N.M. Lopera-Barrero. 2009. Conservación de poblaciones naturales de Brycon orbignyanus y lotes para su sustentabilidad reproductiva, genética y ambiental: Un modelo para especies en extinción. Cien. Inv. Agr. 36(2):191-208. Diversos factores ecológicos y climáticos y especialmente aquellos relacionados con acciones humanas, han llevado a la desaparición de poblaciones naturales de piracanjuba (Brycon orbignyanus). Por la importancia en los ecosistemas en los cuales está ubicada y por sus cualidades de crecimiento rápido y adecuada adaptación a ambientes controlados, en los últimos años el interés de los productores en la utilización de esa especie ha aumentado, con el objetivo de la producción, la mejora económica y la participación en programas de conservación. Con el objetivo de perfeccionar el manejo e monitoreo reproductivo, genético, ambiental y de sanidad de lotes mantenidos en cautiverio y de poblaciones naturales de $B$. orbignyanus, estrategias de manejo sustentable de esa especie son idealizados y discutidos, pudiendo ser usados como modelo para otras especies migratorias amenazadas de extinción.
\end{abstract}

Palabras clave: Banco genético, bienestar animal, Brycon orbignyanus, conservación ambiental, conservación genética, manejo reproductivo, peces, piracanjuba.

\section{References}

Adams, M. 2002. Biological Indicators of Aquatic Ecosystem Stress. American Fisheries Society Bethesda, Maryland, USA. 274 p.

Agostinho, A.A., and L.C. Gomes. 2006. O manejo da pesca em reservatórios da bacia do alto rio Paraná: avaliação e perspectivas. Pages 23-55. In: M.G. Nogueira, , R. Henry y A. Jorcin (eds.). Ecologia de Reservatórios: Impactos Potenciais, Ações de Manejo e Sistemas em Cascatas. RiMA, São Carlos, Brasil.

Agostinho, A.A., S.M. Thomaz, and L.C. Gomes. 2005. Conservation of the Biodiversity of Brazil's inland waters. Conservation Biology 19:646-652.

Ahammad, M.M., D. Bhattacharyya, and B.B. Jana. 2002. The hatching of common carp (Cyprinus carpio L.) embryos in response to exposure to different concentrations of cryoprotectant at low temperatures. Cryobiology 44:114-121.

Ahammad, M.M., D. Bhattacharyya, and B.B. Jana. 2003. Hatching of common carp (Cyprinus carpio L.) embryos stored at 4 and $2{ }^{\circ} \mathrm{C}$ in different concentrations of methanol and sucrose. Theriogenology 60:1409-1422.

Aho, T., J. Rönn, J. Piironen, and M. Björklund. 2006. Impacts of effective population size on genetic diversity in hatchery reared Brown trout (Salmo trutta L.) populations. Aquaculture 253:244-248.
Akaishi, F.M. 2007. Avaliação dos Efeitos Tóxicos de Esgoto Doméstico Tratado e Não Tratado em Bivalve Marinho Mytilus edulis. Tese, Doutorado em Biologia Molecular, Programa de Pós-Graduação em Biologia Celular e Molecular, Universidade Federal do Paraná, Curitiba, Brasil. 55 p.

Andrade, D.R., and G.S. Yasui. 2003. O manejo da reprodução natural e artificial e sua importância na produção de peixes no Brasil. Revista Brasileira de Reprodução Animal 27:166-172.

Aranishi, F. 2006. Single fish egg DNA extraction for PCR amplification. Conservation Genetics 7:153-156

Azevedo, T.M.P. 2004. Parasitofauna e Características Hematológicas de Oreochromis niloticus Mantido em Sistema de Cultivo Integrado e Intensivo no Vale do Rio Tijucas, Santa Catarina. Dissertação, Mestrado em Aqüicultura, Universidade Federal de Santa Catarina, Florianópolis, Brasil. $62 \mathrm{p}$.

Barroso, R.M., A.W.S. Hilsdorf, H.L.M. Moreira, P.H. Cabello, and Y.M. Traub-Cseko. 2005. Genetic diversity of wild and cultured populations of Brycon opalinus (Cuvier, 1819) (Characiforme, Characidae, Bryconiae) using microsatellites. Aquaculture 247:51-65.

Bastos, R.K.X. 2003. Utilização de Esgotos Tratados em Fertirrigação, Hidroponia e Piscicultura. PROSAB, Rio de Janeiro, Brasil. 267 p.

Borba, M.R., D.M. Fracalossi, and L.E. Pezzato. 2006. Dietary energy requirement of piracan- 
juba fingerlings, Brycon orbignyanus, and relative utilization of dietary carbohydrate and lipid. Aquaculture Nutrition 12:183-191.

Braccini, G.L. 2007. Ocorrência de Ectoparasitas em Tilápia do Nilo (Oreochromis niloticus), nas Linhagens Chitralada e GIFT, em Diferentes Densidades e Alimentadas com Dois Níveis de Proteína. Dissertação Mestrado em Zootecnia, Programa de Pós-Graduação em Zootecnia, Universidade Estadual de Maringá, Maringá, Brasil. $45 \mathrm{p}$.

Britto, S.G.C., R.N. Sirol, N.C Vianna, S.M. Jardim, J.C. Santos, and E.Pelisari. 2003. Peixes do rio Paranapanema. São Paulo: Duke Energy Internacional Geração Paranapanema. 112 pp.

Brown, R.C., J.A. Woolliams, and B.J. McAndrew. 2005. Factors influencing effective population size in commercial population of gilthead seabream, Sparus aurata. Aquaculture 247:219225.

Buckup, P.A., and N.A. Menezes. 2003. Catalogo de peixes marinhos e de água doce do Brasil. $2^{\mathrm{a}} \mathrm{Ed}$. http://www.mnrj.ufrj.br/catalogol/. (consultado: octubre de 2007).

Carmo, M., and D.M. Fracalossi. 2002. Dietary protein requirement and energy to protein ratio for piracanjuba (Brycon orbignyanus) Fingerlings. Revista Brasileira de Zootecnia 31:1-10.

Carneiro, P.C.F. 2007. Tecnologias de produção e armazenamento de sêmen de peixes. Revista Brasileira de Reprodução Animal 31:361-366.

Ceccarelli, P.S., J.A. Senhorini, and R.F. Rego. 2005. Piracanjuba, Brycon orbignyanus (Valenciennes, 1849). p. 121-147. In: B Baldisserotto y L.C. Gomes (eds.). Espécies Nativas para Piscicultura no Brasil. Editora da Universidade Federal de Santa Maria, Santa Maria, Brasil.

Dias, P.G., W.M. Furuya, G.C. Pavanelli, M.H. Machado, and R.M. Takemoto. 2004. Carga parasitária de Rondonia rondoni, Travassos, 1920 (Nematoda, Atrictidae) e fator de condição do armado, Pterodoras granulosus, Valenciennes, 1833 (Pisces, Doradidae). Acta Scientiarum Biologycal Sciences 26:151-156.

Egito, A.A., M.S.M. Albuquerque, S.T.R. Castro, S.R. Paiva, J.R.F. Marques, C. McManus, A.S. Mariante, U.P.G. Abreu, S.A. Santos, J.R. Sereno, M.C.S. Fioravanti, C.M. Vaz, F.V. Nobre, J.V. Oliveira, J.H. de Carvalho, M.R. Costa, M.N. Ribeiro, and M.A. Lara. 2005. Situação atual do banco de DNA de recursos genéticos animais no Brasil. Archivos de Zootecnia 54:283-288.
El-Sayed, A.F.M. 2006. Tilapia culture. CABI Publishing, Cambridge University, Cambridge, USA. 277 p.

Faria, R.H.S., M.L.R. Souza, R.P. Ribeiro, and V.M. Fülbe. 2003. Avaliação de diferentes posições de marcação externa em juvenis de tilápia Oreochromis niloticus (Cichlidae). Acta Scientiarum Animal Sciences 25:273-276.

Felizardo, V de O. 2008. Manejo reprodutivo da piracanjuba (Brycon orbignyanus): congelamento de sêmen e taxas de fertilidade. Dissertação (Mestrado em Ciências Veterinárias), Pós-Graduação em Ciências Veterinárias, Universidade Federal de Lavras, Lavras, Brasil. 99 p.

Ferraz, E.M., V.R. Cerqueira, L. Alvarez-Lajonchère, and S. Candido. 2004. O uso de etiquetas externas para identificação de reprodutores do robalopeva, Centropomus parallelus, em tanques. Boletim do Instituto de Pesca 29:183-186.

Fonseca, M.G., and R.J. Silva. 2004. Occurrence of Rondonia rondoni Travassos, 1920 (Nematoda: Atractidae) in the pacu, Piaractus mesopotamicus Holberg, 1887 (Osteichthyes: Characidae) celomatic cavity. Resumo 287. Em: 17 Reunião Anual do Instituto Biológico. São Paulo, Brasil (Resumo).

Froese, R., and D. Pauly. 2003. FishBase. http:// www. fishbase.org (Accessed: October 2007).

Frost, L.A., B.S. Evans, and D.R. Jerry. 2006. Loss of genetic diversity due to hatchery culture practices in barramundi (Lates calcarifer). Aquaculture 261:1056-1064.

Garutti, V. 2003. Piscicultura Ecológica. Editora UNESP, São Paulo, Brasil. 276 p.

Gaston, K.J., and A.S.L. Rodrigues. 2003. Reserve selection in regions with poor biological data. Conservation Biology 17:188-195.

Gaston, K.J., R.L. Pressey, and C.R. Margules. 2002. Persistence and vulnerability: retaining biodiversity in the landscape and in protected areas. Journal of Bioscience 27:361-384.

Géry, J., and V. Mahnert. 1992. Notes on some Brycon (Pisces, Characiformes, Characidae) from the Amazon, Paraná-Paraguay and South-Eastern Brazil Systems. Revue Suisse de Zoologie 99:793-819.

Gomes, P.C. 2007. Diversidade genética de três populações de piapara (Leporinus elongatus), utilizando marcadores moleculares. Dissertação (Mestrado em Zootecnia), Programa de Pós-Graduação em Zootecnia, Universidade Estadual de Maringá, Maringá, Brasil. 75 p. 
Gomes, L.C., R. Roubach, C.A.R.M. Araujo-Lima, A.R. Chippari-Gomes, N.P. Lopes, and E.C. Urbinati. 2003. Effects of fish density during transportation on stress and mortality of juvenile tambaqui, Colossoma macropomum. Journal of World Aquaculture Society 34:76-84.

Graça, W.J., and C.S. Pavanelli. 2007. Peixes da Planície de Inundação do Alto Rio Paraná e Areas Adjacentes. EDUEM, Maringá, Brasil. 241 p.

Groves, C.R., D.B. Jensen, L.L. Valutis, K.H. Redford, M.L. Shaffer, J.M. Scott, J.V. Baumgartner, J.V. Higgins, M.W. Beck, and M.G. Anderson. 2002. Planning for biodiversity conservation: Putting conservation science into practice. Bioscience 52:499-512.

Hiddink, J.D., B.R. MacKenzie, A. Rijnsdorp, N. Dulvy, E.E. Nielsen, D. Bekkevold, M. Heino, P. Lorance, and H. Ojaveer. 2006. Importance of fish biodiversity for the management of fisheries and ecosystems. p. 1-3. In: 2 Annual Meeting of a Fish Biodiversity Responsive Mode Project (Marfish) within the EU Network of Excellence Marine Biodiversity and Ecosystem Functioning (MARBEF). Pärnu, Estonia (Abstract).

Hilsdorf, A., and M. Petrere Jr. 2002. Conservação de peixes na bacia do rio do Paraíba do Sul. Ciência Hoje 30:62-65.

Hori, T.S.F., I.M. Avilez, L.K. Inoue, and G. Moraes. 2006. Metabolical changes induced by chronic phenol exposure in matrinxã Brycon cephalus (teleostei: characidae) juveniles. Comparative Biochemistry and Physiology 143:67-72.

Hussar, G.J., A.L. Paradela, T.C. Jonas, and J.P.R. Gomes. 2005. Tratamento da água de escoamento de tanque de piscicultura através de leitos cultivados de vazão subsuperficial: análise da qualidade física e química. Engenharia Ambiental, Espírito Santo do Pinhal 2:46-59.

Inoue, L.A.K.A. 2005. Respostas do Matrinxã (Brycon cephalus) a Anestésicos e Estressores. Tese Doutorado em Ciências Biológicas, Programa de Pós-Graduação em Genética e Evolução, Universidade Federal de São Carlos, São Carlos, Brasil. $167 \mathrm{p}$.

Leboute, E.M., L.O.B. Afonso, and M.A. Rotta. 2002. Técnica simples de marcação externa de reprodutores de tilápia nilótica (Oreochromis niloticus). Ciência Rural 32:147-149.

Leuzzi, M.S.P., F.S. Almeida, M.L. Orsi, and L.M.K. Sodré. 2004. Analysis by RAPD of the genetic structure of Astyanax altiparanae (Pisces, Characiformes) in reservoirs on the Paranapanema
River, Brazil. Genetics and Molecular Biology 27:355-362.

Lima, F.C.T. 2003. Subfamily Bryconinae (Characins, tetras). Pages 174-181. In: Reis, R.E., S.O. Kullander, and C.J. Ferraris Jr. (eds.). Check List of the Freshwater Fishes of South and Central America. EDIPUCRS, Porto Alegre, Brasil.

Liu, Z.J., and J.F. Cordes. 2004. DNA marker technologies and their applications in aquaculture genetics. Aquaculture 238:1-37.

Livia, L., P. Antonella, L. Hovirag, N. Mauro, and F. Panara. 2006. A nondestructive, rapid, reliable and inexpensive method to sample, store and extract high-quality DNA from fish body mucus and buccal cells. Molecular Ecology Notes 6:257-260.

Lopera-Barrero, N.M. 2005. Diversidade Genética de Populações de Piracanjuba (Brycon orbignyanus) com a técnica de RAPD. Dissertação Mestrado em Zootecnia, Universidade Estadual de Maringá, Maringá, Brasil. 45 p.

Lopera-Barrero, N.M. 2007. Diversidade Genética e Manejo Reprodutivo da Piracanjuba, Brycon orbignyanus. Tese Doutorado em Zootecnia, Programa de Pós-Graduação em Zootecnia, Universidade Estadual de Maringá, Maringá, Brasil. $120 \mathrm{p}$.

Lopera-Barrero, N.M., R.P. Ribeiro, and J.A. Povh. 2007. O repovoamento de peixes: uma estratégia multidisciplinar?. Aqüicultura and Pesca 30:7174.

Lopera-Barrero, N.M., J.A. Povh, R.P. Ribeiro, P.C. Gomes, C.B. Jacometo, and T. da S. Lopes. 2008a. Comparación de protocolos de extracción de ADN con muestras de aleta y larva de peces: extracción modificada con cloruro de sodio. Ciencia e Investigación Agraria 35:77-86.

Lopera-Barrero, N.M., R.P. Ribeiro, R.N. Sirol, J.A. Povh, P.C. Gomes, L. Vargas, and D.P. Streit Jr. 2006. Genetic diversity in piracanjuba populations (Brycon orbignyanus) with the RAPD (Random Amplified Polimorphic DNA) markers. Journal Animal Science 84:170-170.

Lopera-Barrero, N.M., R.P. Ribeiro., R.N. Sirol, J.A. Povh, P.C. Gomes, D.P. Streit Jr, and L. Vargas. 2008b. Genetic characterization of Brycon orbignyanus stocks used in restocking programs. Revista MVZ Córdoba 13:1110-1119.

Lupchinski, E., L. Vargas, R.P. Ribeiro, H.L.M. Moreira, M. Valentim, and J.A. Povh. 2006. A importância da utilização da técnica de RAPD para a identificação de dactilogirídeos em Tilá- 
pias do Nilo (Oreochromis niloticus). Arquivos de Ciências Veterinárias e Zoología da UNIPAR 9:49-57.

Lupi, C., N.I. Nhacarini, A.F. Mazon, and O.R. Sá. 2007. Avaliação da poluição ambiental através das alterações morfológicas nas brânquias de Oreochromis niloticus (tilapia) nos córregos Retiro, Consulta e Bebedouro, município de Bebedouro-SP. Revista Fafibe (on-line) 3:1-6.

Machado, A.B.M. 2005. Lista da fauna brasileira ameaçada de extinção: incluindo as espécies quase ameaçadas e deficientes em dados. Pages. 160. In: Machado, A.B.M., C.S. Martins, and G.M. Drummond (eds.). Lista da Fauna Brasileira Ameaçada de Extinção Fundação Biodiversitas, Belo Horizonte, Brasil.

Mateus, L.A. de F., and G.M.B. Estupiñán. 2002. Fish stock assessment of piraputanga Brycon microlepis in the Cuiabá river basin, Pantanal of Mato Grosso, Brazil Brazilian Journal of Biology 62:165-170.

Medeiros, F.C. 2002. Tanque-Rede: Mais Tecnologia e Lucro na Piscicultura. Editora Cuiabá, Cuiabá, Brasil. 110 p.

Metzger, J.P., and L. Casatti. 2006. Do diagnóstico à conservação da biodiversidade: o estado da arte do programa BIOTA/FAPESP. Biota Neotropica 6:1-23.

Ministerio do Médio Ambiente. 2007. Biodiversidade e florestas: espécies ameaçadas. http://www. mma.gov.br. (Accessed: October 2007).

Monteiro, D.A., J.A. Almeida, F.T. Rantin, and A.L. Kalinin. 2006. Oxidative stress biomarkers in the freshwater characid fish, Brycon cephalus, exposed to organophosphorus insecticide Folisuper 600 (methyl parathion). Comparative Biochemistry and Physiology 143:141-149.

Nakatani, K., A.A. Agostinho, G. Baumgartner, A. Bialetzki, P.V. Sanches, M.C. Makrakis, and C.S. Pavanelli. 2003. p. 120-124. In: Ovos e larvas de peixes de água doce. EDUEM, Maringá, Brasil.

Ninhaus-Silveira, A., F. Foresti, R. Veríssimo-Silveira, and J.A. Senhorini. 2006. Seminal Analysis, Cryogenic preservation, and fertility in Matrinxã Fish, Brycon cephalus (Günther, 1869). Brazilian Archives of Biology and Technology 49:651659.

Pavanelli, G.C., J.C. Eiras y R.M. Takemoto. 2002. Doenças de peixes: profilaxia, diagnóstico e tratamento. EDUEM, Maringá, Brasil. 305 pp.

Pineda-Santis, H.R., D. Pareja-Molina, M. OliveraAngel, and J. Builes-Gómez. 2004. Contribución a la relación taxonómica entre cuatro especies de peces de la familia Characidae mediante el Polimorfismo de ADN Amplificado al Azar (RAPD). Revista Colombiana de Ciencias Pecuarias 17:30-37.

Pilarski, F., A.J. Rossini, and P.S. Ceccarelli. 2008. Isolation and characterization of Flavobacterium columnare (Bernardet et al. 2002) from four tropical fish species in Brazil. Brazilian Journal of Biology 68:409-414.

Povh, J.A., N.M. Lopera-Barrero, R.P. Ribeiro, E. Lupchinski Jr., P.C. Gomes, and T.S. Lopes. 2008. Monitoreo genético en programas de repoblamiento de peces mediante marcadores moleculares. Ciencia e Investigación Agraria 35:515.

Povh, J.A. 2007. Avaliação da Diversidade Genética e do Manejo Reprodutivo do Pacu, Piaractus mesopotamicus. Tese Doutorado em Zootecnia, Programa de Pós-Graduação em Zootecnia, Universidade Estadual de Maringá, Maringá, Brasil. $75 \mathrm{p}$.

Reis, R.E., S.O. Kullander, and C.J. Ferrari Jr. 2003. Check listo $f$ the freshwater fishes of South and Central America. EDPUCRS, Porto Alegre, Brasil. $729 \mathrm{pp}$.

Reynalte-Tataje, D., D.M. Esquivel, J.R. Esquivel, and E. Zaniboni-Filho. 2002b. Reprodução indizida do piauçu, Leporinus macrocephalus, (Characiformes, Anostomidae). Boletim do Instituto de Pesca 28:11-18.

Reynalte-Tataje, D., R.K. Luz, S. Meurer, E. Zaniboni-Filho, and A.P.O. Nuñer. 2002a. Influência do fotoperíodo no crescimento e sobrevivência de pós-larvas de piracanjuba Brycon orbignyanus (Valenciennes, 1849)(Osteichthyes, Characidae). Acta Scientiarum Animal Sciences 24:439-443.

Sá, M.F.P., N. Fenerich-Verani, and E.N. Fragoso. 2003. Peixes do cerrado em perigo. Ciência Hoje 34:68-71.

Sabino, J., and L.P. Andrade. 2002. Monitoramento e conservação no rio Baía Bonita, região de Bonito, Mato Grosso do Sul, Brasil. p. 397-404. In: Anais do III Congresso Brasileiro de Unidades de Conservação. Rede Pró-Unidades de Conservação, Fundação Boticário de Proteção à Natureza e Associação Caatinga. Fortaleza, Brasil (Resumo).

Sabino J., and L.P. Andrade. 2003. Uso e conservação da ictiofauna no ecoturismo da região de Bonito, Mato Grosso do Sul: o mito da sustentabilidade 
ecológica no rio Baía Bonita (Aquário natural de Bonito). Biota Neotropica 3:1-9.

Sanches, A., and P.M. Galetti Jr. 2006. Microsatellites loci isolated in the freshwater fish Brycon Hilarii. Molecular Ecology Notes 6:1045-1046.

Schalch, S.H.C., F.R. Moraes, and J.R.E. Moraes, 2006. Efeitos do parasitismo sobre a estrutura branquial de Leporinus macrocephalus Garavello e Britsk, 1988 (Anastomidae) e Piaractus mesopotamicus Holmberg, 1887 (Osteichthyes: Chararacidae). Revista Brasileira de Parasitologia Veterinária 5:110-115.

Schalch, S.H.C., and F.R. Moraes. 2005. Distribuição sazonal de parasitos branquiais em diferentes espécies de peixes em pesque-pague do município de Guariba-SP, Brasil. Revista Brasileira de Parasitologia Veterinária 14:141-146.

Sibinelli, V. 2003. Um mutirão pró-piabanha. Terra da Gente. http://www.terradagente.com.br. (Accessed: October 2007).

Silva, J.M.A. 2007a. Características Reprodutivas de Curimba (Prochilodus lineatus), Pacu (Piaractus mesopotamicus) e Piracanjuba (Brycon orbignyanus). Dissertação Mestrado em Zootecnia, Programa de Pós-Graduação em Zootecnia, Universidade Federal de Lavras, Lavras, Brasil. $75 \mathrm{p}$.

Silva, N.A. 2007b. Caracterização de impactos gerados pela piscicultura na qualidade da água: estudo de caso na bacia do rio Cuiabá/MT. Dissertação (Mestrado em Física e Meio Ambiente) Universidade Federal de Mato Grosso do Sul, Campo Grande, Brasil. 120 p.

Sirol, R.N., and S.G. Britto. 2006. Conservação e manejo da ictiofauna: repovoamento. Pages 275 284. In: M.G. Nogueira, R. Henry, and A. Jorcin (eds.). Ecologia de Reservatórios: Impactos Potenciais, Ações de Manejo e Sistemas em Cascatas. RiMA, São Carlos, Brasil.

Sipaúba-Tavares, L.H., E.J. da S. Alvarez, and F.M. de S. Braga. 2008. Water quality and zooplankton in tanks with larvae of Brycon orbignyanus (Valenciennes, 1949). Brazilian Journal of Biology 68:77-86.

Sofia, S.H., C.R.M. Silva, B.A. Galindo, F.S. Almeida, L.M.K. Sodré, and C.B.R. Martinez. 2006. Population genetic structure of Astyanax scabripinnis (Teleostei, Characidae) from an urban stream. Hydrobiologia 553: 245-254.

Sønstebø, J.H., R. Borgstrøm, and M. Heun. 2007. Genetic structure of brown trout (Salmo trutta L.) from the Hardangervidda mountain plateau
(Norway) analyzed by microsatellite DNA: a basis for conservation guidelines. Conservation Genetics 8:33-44.

Streit Jr., D.P. 2005. Embriões de pacu (Piaractus mesopotamicus) tratados com metanol e DMSO e submetidos ao resfriamento. Tese (Doutorado em Zootecnia), Programa de Pós-Graduação em Zootecnia, Universidade Estadual de Maringá, Maringá, Brasil. 80 p.

Streit Jr., D.P., M. Digmayer, R.P. Ribeiro, R.N. Sirol, G.V. Moraes, and J.M. Galo. 2007. Embriões de pacu submetidos a diferentes protocolos de resfriamento. Pesquisa Agropecuária Brasileira 42:1199-1202.

Suarez-Mahecha, H. 2002. Efeito do Resfriamento Sobre a Textura Post-mortem da Carne do Matrinxã Brycon cephalus (Pisces: Characiforme). Dissertação Mestrado em Ciências dos Alimentos, Curso de Pós-Graduação em Ciências e Tecnologia de Alimentos, Universidade Federal de Santa Catarina, Florianópolis, Brasil. 66 p.

Taniguchi, N. 2003. Genetic factors in broodstock management for seed production. Reviews Fish Biology and Fisheries 13:175-185.

Terborgh, J., C.V. Schaik, L. Davenport, and M. Rao. 2002. Tornando os parques eficientes: estratégias para conservação da natureza nos trópicos. Editora da UFPR. Fundação O Boticário de Proteção à Natureza, Curitiba, Brasil. $280 \mathrm{p}$.

Toledo, J.J., J.G.D. Castro, K.F. Santos, R.A. Farias, S. Hacon, and W. Smermann. 2003. Avaliação do impacto ambiental causado por efluentes de viveiros da Estação de Pisciculturas de Alta Floresta-MT. Revista do Programa de Ciências Agro-Ambientais, Alta Floresta 2:13-31.

Vargas, L., R.H.S. Faria, R.P. Ribeiro, L.S. Merlini, H.L.M. Moreira, and J.C. Toninato. 2003. Ocorrência sazonal de ectoparasitos em tilápias de Nilo (Oreochromis niloticus) em um "pesque-pague" de Umuarama, Paraná. Arquivos de Ciências Veterinárias e Zoologia da UNIPAR 6:61-66.

Wasko, A.P. 2005. A importância do monitoramento genético em estoques cultivados de matrinxã e piracanjuba. Revista Panorama da Aqüicultura 15:47-49.

Wasko, A.P., and P.M. Galetti Jr. 2002. RAPD analysis in the Neotropical fish Brycon lundii: genetic diversity and its implications for the conservation of the species. Hydrobiologia 474:131-137.

Wasko, A.P., and P.M. Galetti Jr. 2003. PCR primed with microsatellite core sequences yields speciesspecific patterns and assessment of population 
variability in fishes of the genus Brycon. Journal of Applied Ichthyology 19:109-113.

Wasko, A.P., C. Martins, C. Oliveira, and F. Foresti. 2003. Nondestructive genetic sampling in fish. An improved method for DNA extraction from fish fins and scales. Hereditas 138:161-165.

Wasko, A.P., C. Martins, C. Oliveira, J.A. Senhorini y F. Foresti. 2004. Genetic monitoring of the Amazonian fish matrinchã (Brycon cephalus) using RAPD markers: insights into supportive breeding and conservation programmers. Journal Applied of Ichthyology 20:48-52.

Zaniboni-Filho, E., and U.H. Schulz. 2003. Migratory Fishes of the Uruguay River. In: Carolsfeld, J., B. Harvey, C. Ross and A. Baer (eds.). Migratory Fishes of South America. Biology, Fisheries and Conservation Status. World Fisheries Trust, Victoria, Canada.

Zaniboni-Filho, E. y A.P.O. Nuñer. 2004. Fisiologia da reprodução e propagação artificial dos peixes. Pages 45-73. In: J.E.P.Cyrino, E.C. Urbinati, D.M. Fracalossi, and N. Castagnolli (eds.). Tópicos Especiais em Piscicultura de Agua Doce Tropical Intensiva. TecArt, São Paulo, Brasil.

Zaniboni-Filho, E., and M. Weinggartner. 2007. Técnicas de indução da reprodução de peixes migradores. Revista Brasileira de Reprodução Animal 31:367-373.

Zaniboni-Filho, E., D. Reynalte-Tataje, and M. Weingartner. 2006. Potencialidad del género Brycon en la piscicultura brasileña. Revista Colombiana de Ciencias Pecuarias 19:233-240. 
